\title{
Analisis Penerimaan Sistem Informasi Pencatatan dan Pelaporan Kasus COVID-19 (Aplikasi Silacak Versi 1.2.5) Menggunakan Technology Acceptance Model (TAM) di UPT Puskesmas Cipadung Kota Bandung
}

\author{
Nurfatia Negari, Tris Eryando \\ Departmen Biostatistika dan Ilmu Kependudukan Fakultas Kesehatan Masyarakat \\ Universitas Indonesia
}

*Korespondensi: Nurfatia Negari - nurfatianegari@gmail.com

\begin{abstract}
Abstrak
Salah satu upaya untuk mengendalikan laju COVID-19 ialah dengan memperkuat sistem surveilans di fasilitas kesehatan tingkat dasar. Salah satu poin yang menjadi peran kunci dalam pemutusan rantai penularan COVID-19 adalah kegiatan pelacakan kontak. Kegiatan ini mengharuskan pelacak kontak untuk terus mencatat dan melaporkan kasus. Untuk itu, penggunaan sistem pencatatan dan pelaporan pelacakan kontak (Silacak) menjadi penting dalam menentukan kebijakan yang akan dibuat. Tujuan penelitian ini adalah menelaah penggunaan sistem pencatatan dan pelaporan COVID-19 dengan aplikasi Silacak serta penerimaan pengguna terhadap sistem informasi Silacak di UPT Puskesmas Cipadung Kota Bandung. Penelitian ini merupakan studi kualitatif dengan menggunakan desain studi kasus. Aplikasi Silacak cukup bermanfaat bagi proses pencatatan dan pelaporan COVID-19. Aplikasi ini mudah untuk dipelajari, namun masih perlu dilakukan perbaikan dan pengembangan di beberapa sisi.
\end{abstract}

Keyword: COVID-19, pelacakan kontak, silacak, pencatatan dan pelaporan

\section{Analysis of Receiving Information System Recording and Reporting of COVID-19 Case (Silacak Application Version 1.2.5) Using Technology Acceptance Model (Tam) at UPT Puskesmas Cipadung, Bandung City}

\begin{abstract}
One of the efforts to control the rate of COVID-19 is to strengthen the surveillance system at primary health facilities. One of the points that has played as a key role in breaking the COVID-19 chain of transmission is by contact tracing. This activity requires contact tracers to continuously record and report cases. For this reason, the use of a contact tracking recording and reporting system (Silacak) is important in determining the policies to be made. This study aimed to analyze the use of the COVID-19 recording and reporting system with the Silacak application as well as user acceptance of the Silacak information system at Cipadung Health Center, Bandung City. This study was qualitative study using case study design. Silacak application is a useful media for COVID19 recording and reporting. This application is easy to learn but it still needs improvement and development on several sides.
\end{abstract}

Keywords: COVID-19, Contact tracing, Silacak, Recording and Reportin 
PENDAHULUAN

COVID-19 adalah penyakit menular yang diakibatkan oleh Severe Acute Respiratory Syndrome Coronavirus 2 (SARS-CoV-2) yang menyerang sistem pernapasan. SARS-CoV-2 merupakan Coronavirus jenis baru yang belum pernah diidentifikasi sebelumnya pada manusia. Penyakit ini pertama kali terdeteksi kemunculannya di Wuhan Tiongkok pada bulan Desember 2019, dan kini telah menyebar luas ke seluruh belahan dunia, termasuk Indonesia. Transmisi penyebaran COVID-19 dari manusia ke manusia menjadi sumber transmisi utama sehingga penyebarannya menjadi lebih agresif. Penularan SARS-CoV-2 terjadi melalui droplet yang keluar saat batuk atau bersin (1).

Badan Kesehatan Dunia (WHO) telah menetapkan fenomena COVID-19 sebagai pandemi pada tanggal 11 Maret 2020. Secara nasional juga telah ditetapkan sebagai bencana nasional, melalui Keputusan Badan Nasional Penanggulangan Bencana (BNPB) Nomor 9A Tahun 2020 tentang Penetapan Status Keadaan Tertentu Darurat Bencana Wabah Penyakit Akibat Virus Corona di Indonesia (2).

Meluasnya penyebaran COVID-19 telah menyebabkan jatuhnya banyak korban jiwa, mengganggu kehidupan dan penghidupan masyarakat Indonesia, serta berimplikasi pada aspek sosial ekonomi yang luas di Indonesia, maka dari itu Presiden menerbitkan Keputusan Presiden Republik Indonesia Nomor 12 Tahun 2020 tentang Penetapan Bencana Non-alam Penyebaran Coronavirus Disease 2019 (COVID-19) Sebagai Bencana Nasional (2).

Berdasarkan data yang diperoleh dari laman Satgas COVID-19, kasus COVID-19 per tanggal 22 Februari 2021 berjumlah 1.278.653 kasus terkonfirmasi, dengan 157.088 kasus aktif di seluruh Indonesia. Melihat jumlah kasus COVID-19 yang terus meningkat, maka perlu adanya upaya pengendalian. Salah satu upaya untuk mengendalikan laju COVID-19 ialah dengan memperkuat sistem surveilans di tingkat Puskesmas. Melalui sistem surveilans, kasus COVID-19 dapat dilacak, dianalisa, hingga menghasilkan informasi untuk menghasilkan informasi yang dapat digunakan dalam pengendalian penularan penyakit (3). Salah satu strategi surveilans yang amat gencar dilakukan selama pandemi COVID-19 adalah 3T (Testing, Tracing, dan Treatment).

Era globalisasi seperti saat ini, sistem informasi diperlukan untuk mempermudah pencatatan dan pelaporan suatu penyakit. Sistem informasi adalah suatu sistem di dalam suatu organisasi yang mempertemukan kebutuhan pengolahan 
transaksi harian yang mendukung fungsi operasi organisasi yang bersifat manajerial, dengan kegiatan strategi dari suatu organisasi untuk dapat menyediakan kepada pihak luar tertentu dengan laporan-laporan yang diperlukan (4).

Sistem informasi menjadi media komunikasi yang sangat penting antara petugas lapangan dengan pemangku kebijakan untuk mengendalikan pandemi COVID-19. Pada November 2020, Kementerian Kesehatan meluncurkan sebuah sistem informasi yang dirancang untuk memperkuat sistem surveilans, khususnya untuk kegiatan pelacakan kontak, yang bernama Silacak. Silacak adalah sebuah sistem informasi berbasis website yang dirancang untuk pelacakan kontak, memfasilitasi analisis data, serta pemantauan harian di Puskesmas dan di tingkat Kabupaten/Kota (5).

Melihat dari semakin cepatnya penularan COVID-19 di Indonesia, khususnya di Kota Bandung, Silacak menjadi salah satu aplikasi yang diperlukan guna memfasilitasi analisis data COVID-19 pemantauan kasus COVID-19 harian di puskesmas dan di tingkat kabupaten/kota, serta visualisasi untuk mendukung pengambilan keputusan berdasarkan bukti (5). Kemunculan aplikasi Silacak pasti akan menimbulkan sikap penerimaan ataupun penolakan dari penggunanya, maka dari itu untuk mengetahui apakah aplikasi tersebut dapat diterima atau ditolak oleh pengguna diperlukan analisis untuk mengetahuinya. Penulis memilih teori Technology Acceptance Model (TAM) untuk memberikan penjelasan terhadap penggunaan dan penerimaan aplikasi Silacak.

Technology Acceptance Model (TAM) dikembangkan oleh Fred Davis pada tahun 1989 sebagai acuan untuk memahami perilaku pengguna dalam menerima dan menggunakan sebuah sistem informasi. Teori ini memiliki dua komponen yaitu perceived usefulness (persepsi kebermanfaatan) yaitu sejauh mana seseorang percaya bahwa dengan menggunakan teknologi dapat meningkatkan kinerjanya, dan perceived ease of use (persepsi kemudahan penggunaan) ialah tingkat keyakinan seseorang bahwa penggunaan teknologi, dapat menyelesaikan pekerjaan dengan lebih mudah (6).

Tujuan dari penelitian ini adalah menelaah sistem pencatatan dan pelaporan COVID-19 melalui aplikasi Silacak serta penerimaan pengguna terhadap sistem informasi Silacak di UPT Puskesmas Cipadung Kota Bandung.

\section{METODE}

Desain yang digunakan dalam pengamatan ini adalah studi kualitatif 
dengan menggunakan desain studi kasus. Teknik pengumpulan data yang digunakan adalah Wawancara Mendalam dan Observasi Terstruktur. Pengamatan ini memiliki maksud untuk memahami persepsi subjek pengamatan terhadap kemudahan dan kegunaan aplikasi Silacak, serta menggali pemahaman mengenai penerimaan subjek pengamatan terhadap sistem informasi tersebut dalam kegiatan pencatatan dan pelaporan COVID-19 dengan menggunakan teori TAM. Adapun kerangka konsep yang digunakan pada penelitian ini dapat dilihat pada Gambar 1.

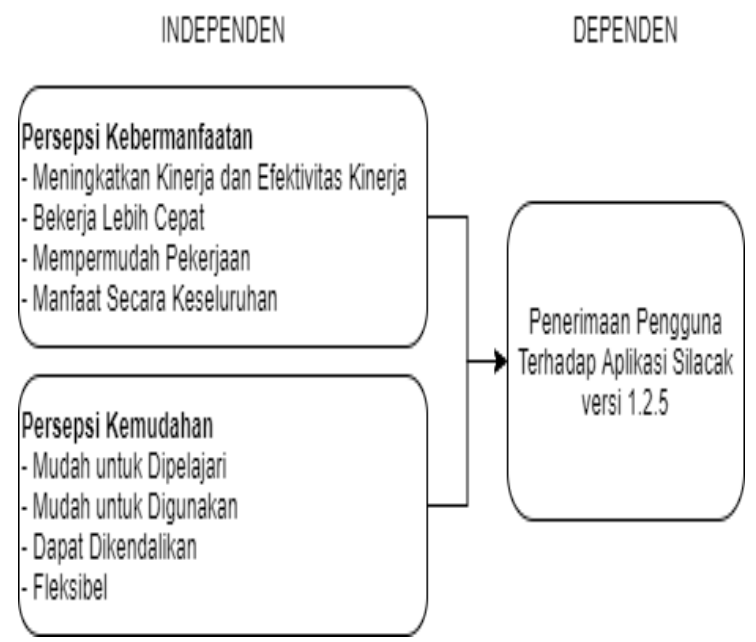

Gambar 1. Kerangka Konsep

Pengamatan dilakukan di UPT Puskesmas Cipadung Kota Bandung, yang dilaksanakan pada tanggal 15 Maret 2021 hingga 9 April 2021. Penetapan subjek dilakukan dengan menggunakan purposive sampling. Subjek yang diamati adalah tiga orang petugas pelacak kontak di UPT
Puskesmas Cipadung selaku pengguna aplikasi Silacak.

\section{HASIL}

Berdasarkan observasi yang telah dilaksanakan, diketahui terdapat tiga orang pelacak kontak yang dipimpin oleh satu orang petugas surveilans yang merangkap menjadi bidan di UPT Puskesmas Cipadung. Petugas pelacak kontak mengetahui kasus yang perlu dilacak melalui notifikasi yang didapatkan dari Dinas Kesehatan Kota Bandung. Setelah mendapatkan notifikasi, petugas pelacak kontak mulai melakukan wawancara kepada kasus konfirmasi dengan menggunakan Formulir 6 Penyelidikan Epidemiologi sebagai pedomannya.

Perangkat yang biasa digunakan untuk mengakses Silacak diantaranya ialah komputer Puskesmas, laptop dan telepon genggam pribadi para pelacak kontak. Seluruh perangkat tersedia dalam kondisi baik. Router disediakan di UPT Puskesmas Cipadung, untuk memudahkan akses terhadap internet dalam mengakses website Silacak dan sebagai akses bagi petugas pelacak kontak untuk bertukar informasi. Terdapat pedoman penggunaan aplikasi Silacak pada website Silacak dalam bentuk e-book dan video. 
Tabel 1. Hasil Observasi Elemen Input, Proses, dan Output pada Penggunaan Aplikasi Silacak di UPT Puskesmas Cipadung

\begin{tabular}{|c|c|c|c|}
\hline Observasi & Ya & Tidak & Keterangan \\
\hline \multicolumn{4}{|l|}{ Input } \\
\hline a. Terdapat petugas penginput data & $\sqrt{ }$ & - & - \\
\hline b. Tersedia Formulir 6 Penyelidikan Epidemiologi (PE) & $\sqrt{ }$ & - & - \\
\hline c. Kelengkapan data untuk diinput & $\sqrt{ }$ & - & - \\
\hline $\begin{array}{l}\text { d. Laptop dan telepon genggam yang digunakan tersedia } \\
\text { dalam kondisi baik }\end{array}$ & $\sqrt{ }$ & - & - \\
\hline e. Tersedia koneksi internet & $\sqrt{ }$ & - & Menggunakan Wi-Fi \\
\hline f. Terdapat e-book pedoman penggunaan Silacak & $\sqrt{ }$ & - & - \\
\hline \multicolumn{4}{|l|}{ Proses } \\
\hline a. Petugas melakukan input data ke Silacak secara rutin & $\sqrt{ }$ & - & $\begin{array}{l}\text { Dilakukan satu hingga dua hari } \\
\text { sekali }\end{array}$ \\
\hline $\begin{array}{l}\text { b. Petugas mengisi secara lengkap kolom yang tersedia di } \\
\text { aplikasi Silacak }\end{array}$ & - & $\sqrt{ }$ & Kolom koordinat tidak selalu diisi \\
\hline c. Petugas menggunakan Silacak sesuai dengan pedoman & $\sqrt{ }$ & - & - \\
\hline d. Petugas melakukan back up data & $\sqrt{ }$ & - & $\begin{array}{l}\text { Tersedia dalam form PE dan } \\
\text { google spreadsheet }\end{array}$ \\
\hline \multicolumn{4}{|l|}{ Output } \\
\hline a. Laporan dikirimkan ke Dinas Kesehatan secara rutin & $\sqrt{ }$ & - & - \\
\hline b. Laporan dikirimkan ke Dinas Kesehatan tepat waktu & $\sqrt{ }$ & - & - \\
\hline $\begin{array}{l}\text { c. Terdapat dashboard untuk melihat jumlah kasus yang } \\
\text { berhasil diinput pada masing-masing puskesmas. }\end{array}$ & $\sqrt{ }$ & - & $\begin{array}{l}\text { Tidak semua petugas mengetahui } \\
\text { keberadaan dashboard }\end{array}$ \\
\hline
\end{tabular}

Petugas pelacak kontak memasukkan data ke dalam aplikasi Silacak setiap satu hingga dua hari sekali. Hal ini disebabkan oleh beberapa faktor diantaranya tidak menentunya notifikasi yang diterima oleh petugas surveilans, jumlah pasien yang dilacak, dan kondisi khusus apabila terjadi pemeliharaan aplikasi Silacak. Data yang dimasukkan oleh petugas yaitu data yang telah didapatkan dan dicatat pada Form 6 Penyelidikan Epidemiologi pada saat melakukan pelacakan kontak, sehingga petugas memiliki arsip data dalam format manual. Sebagian besar format isian di aplikasi Silacak terisi dengan lengkap. Namun, untuk kolom koordinat tempat tinggal kasus terkonfirmasi tidak selalu diisi oleh petugas, disebabkan karena tidak menentunya jadwal kunjungan rumah.

Melalui aplikasi Silacak, data yang diinput oleh petugas pelacak kontak langsung diterima oleh Data Manager di Dinas Kesehatan Kota Bandung. Ketepatan waktu dalam pengiriman laporan sangat bergantung kepada kondisi aplikasi Silacak. Apabila sedang dilakukan perbaikan pada aplikasi Silacak, maka pengiriman laporan ditunda hingga Silacak dapat diakses kembali. Data yang telah terkirim akan divalidasi dan direkapitulasi oleh Dinas Kesehatan Kota Bandung. Setelah itu, Dinas Kesehatan Kota Bandung akan memberikan umpan balik bagi Puskesmas terkait pencapaian pelacakan kontak setiap satu bulan sekali. Adapun hasil observasi 
terhadap elemen input, proses, dan output pada aplikasi Silacak dapat dilihat dalam Tabel 1.

\section{Persepsi Kebermanfaatan}

Persepsi kebermanfaatan atau perceived usefulness adalah kepercayaan pengguna bahwa pemanfaatan teknologi mampu meningkatkan prestasi kerja atau performa penggunanya. Menurut Davis (2000) dalam Irmadhani dan Nugroho (2011) indikator yang mempengaruhi persepsi kebermanfaatan diantaranya apabila kehadiran teknologi tersebut membantu meningkatkan kinerja dan efektivitas kinerja, meningkatkan produktivitas, mempermudah pekerjaan pengguna, dan sistem yang digunakan bermanfaat bagi pengguna $(7,8)$.

Melalui wawancara yang telah dilakukan kepada tiga orang informan, diketahui bahwa aplikasi Silacak dalam kegiatan pencatatan dan pelaporan COVID19 mempunyai beberapa manfaat. Manfaatmanfaat yang dirasakan oleh informan diantaranya yaitu memudahkan dalam mengetahui data kasus konfirmasi aktif, mengetahui kondisi kesehatan kontak erat dari kasus yang dipantau, serta mengetahui kapan masa isolasi berakhir. Selain itu, aplikasi Silacak juga bermanfaat untuk menjadi media pelaporan kasus aktif COVID-19 beserta kontak eratnya kepada Dinas Kesehatan Kota Bandung.
Meskipun Silacak memiliki manfaat yang baik, rupanya aplikasi ini memiliki kekurangan. Diantaranya yaitu proses penyimpanan aplikasi Silacak yang cukup lama akibat sering dilakukannya perbaikan sistem di jam kerja, sehingga terkadang petugas harus melakukan input data di malam hari atau bahkan saat dini hari, dan kurangnya fitur pemantauan kesehatan harian pada pasien terkonfirmasi.

Penggunaan aplikasi Silacak di UPT Puskesmas Cipadung tidak membuat pekerjaan petugas menjadi lebih cepat diselesaikan. Informan menyatakan bahwa penyebab terjadinya hal tersebut ialah akibat dari sering terjadinya gangguan koneksi pada aplikasi Silacak. Petugas juga merasa pekerjaannya tidak lebih cepat selesai karena tidak adanya otomatisasi dalam pengisian data identitas pasien, serta banyaknya aplikasi pencatatan dan pelaporan COVID-19 yang perlu dilakukan oleh Puskesmas.

Pada indikator kinerja, seluruh informan menyatakan bahwa dengan menggunakan aplikasi Silacak, kinerja informan di Puskesmas dapat terpantau. Kinerja tersebut disampaikan oleh Dinas Kesehatan khususnya data manager melalui percakapan grup WhatsApp setiap satu bulan sekali dalam bentuk prosentase pencapaian pelacakan kontak sebagai umpan balik dari proses tracing yang dilakukan oleh tim pelacak kontak di 
Puskesmas. Melalui umpan balik tersebut, kinerja tim pelacak kontak dapat ditingkatkan ataupun dipertahankan. Selain itu, informan merasa bahwa kehadiran aplikasi ini mempermudah proses pencarian data pasien, dibandingkan dengan mencari data secara manual melalui berkas formulir penyelidikan epidemiologi.

Hasil wawancara juga menunjukkan bahwa setelah mendapatkan umpan balik dari Dinas Kesehatan, informan menjadi lebih terpacu untuk dapat memenuhi target pelacakan kontak erat yang ditentukan setelah mendapatkan umpan balik dari Dinas Kesehatan. Hal ini menunjukkan bahwa pengisian aplikasi Silacak memberikan dampak positif terhadap efektivitas kinerja.

Pernyataan informan terhadap pertanyaan terkait produktivitas, diperoleh kesimpulan bahwa seluruh informan merasa penggunaan aplikasi Silacak tidak meningkatkan produktivitas informan. Hal ini disebabkan oleh seringnya terjadi gangguan sistem, serta adanya perbaikan di jam-jam kerja. Hal tersebut mengakibatkan tertundanya pekerjaan hingga aplikasi dapat digunakan kembali atau hingga proses perbaikan selesai.

Mengetahui manfaat dari aplikasi Silacak, sebagian besar informan merasa aplikasi Silacak membantu mempermudah pekerjaan mereka. Namun, salah satu informan merasa penggunaan aplikasi
Silacak tidak membuat pekerjaannya menjadi lebih mudah. Hal ini disebabkan oleh faktor eksternal yaitu banyaknya format-format pelaporan COVID-19 yang perlu diisi meskipun petugas sudah mengisi di Silacak.

\section{Persepsi Kemudahan (Ease of Use)}

Persepsi kemudahan atau perceived ease of use adalah tingkatan dimana seseorang percaya bahwa teknologi dapat menyelesaikan pekerjaan dengan lebih mudah. Indikator persepsi kemudahan teknologi informasi sebagaimana dijabarkan oleh Davis (1989) dan Noviarni (2014) dalam Deisti (2018) antara lain mudah dipahami, mudah digunakan, dapat dikendalikan, dan fleksibel $(7,9,10)$.

Dari hasil wawancara didapatkan kesimpulan bahwa seluruh informan telah mendapatkan pelatihan mengenai tata cara penggunaan aplikasi Silacak secara daring dengan Dinas Kesehatan Kota Bandung dan BNPB. Informan menyatakan bahwa aplikasi ini mudah untuk dipelajari dan digunakan. Aplikasi Silacak telah dilengkapi dengan pedoman penggunaannya. Informan menyatakan bahwa pedoman yang tersedia mudah untuk dipahami, meskipun pedomannya tidak diperbaharui seiring dengan perbaikanperbaikan dan pembaharuan sistem yang dilakukan oleh pusat. 
Hasil wawancara diperoleh informasi bahwa data yang dimasukkan ke dalam aplikasi Silacak kurang dapat dikendalikan. Sebagai contoh, apabila ditemukan penyintas COVID-19 yang mengalami reinfeksi, petugas tidak dapat menginput ulang data tersebut. Petugas pelacak kontak tidak dapat melihat riwayat pasien yang sudah selesai dipantau. Solusi untuk permasalahan ini yaitu petugas harus menghubungi data manager agar dapat mengakses kembali data tersebut. Akan tetapi, informan merasa aplikasi Silacak cukup fleksibel. Informan menyatakan bahwa aplikasi Silacak dapat diakses dimana saja dan kapan saja melalui laptop dan telepon genggam. Jika aplikasi mengalami gangguan, informan juga dapat dengan mudah menutup laman Silacak.

\section{Harapan}

Pengguna aplikasi Silacak di UPT Puskesmas Cipadung berharap aplikasi Silacak dapat diintegrasikan dengan sistem Disdukcapil, untuk mempermudah proses input identitas pasien.

Tabel 2. Ringkasan Hasil Wawancara Mendalam pada Pengguna Aplikasi Silacak di UPT Puskesmas Cipadung

\begin{tabular}{|c|c|c|c|}
\hline Kriteria & INF 1 & INF 2 & INF 3 \\
\hline \multicolumn{4}{|c|}{ Persepsi Kebermanfaatan } \\
\hline Manfaat & $\begin{array}{l}\text { Jadi tahu siapa saja yang } \\
\text { positif di wilayah kita, } \\
\text { siapa kontak eratnya. } \\
\text { Punya wadah untuk } \\
\text { menyimpan data yang kita } \\
\text { dapatkan. }\end{array}$ & $\begin{array}{l}\text { Jadi punya data pasien positif. } \\
\text { Karena kasusnya banyak, kalau } \\
\text { misalnya lupa, bisa pantau dari } \\
\text { aplikasi ini. }\end{array}$ & $\begin{array}{l}\text { Memudahkan pemantauan, } \\
\text { bermanfaat sebagai } \\
\text { laporan ke dinas, jadi lebih } \\
\text { simple karena punya data } \\
\text { digital, jadi tidak terus } \\
\text { menerus buka buku. }\end{array}$ \\
\hline $\begin{array}{l}\text { Mempercepat } \\
\text { Pekerjaan }\end{array}$ & $\begin{array}{l}\text { Relatif, karena alatnya } \\
\text { suka lemot dan sulit } \\
\text { diakses. Bagi saya jika } \\
\text { alatnya cepat mungkin } \\
\text { bisa mempermudah } \\
\text { (mempercepat). }\end{array}$ & $\begin{array}{l}\text { Bisa aja, asal aplikasinya tidak } \\
\text { sering loading. }\end{array}$ & $\begin{array}{l}\text { Tidak. Aplikasinya sering } \\
\text { lemot. Banyak kolom } \\
\text { identitas yang harus diisi, } \\
\text { tapi tidak bisa otomatis } \\
\text { ambil dari Dukcapil. }\end{array}$ \\
\hline $\begin{array}{l}\text { Meningkatkan } \\
\text { Kinerja dan } \\
\text { Efektivitas } \\
\text { Kinerja }\end{array}$ & $\begin{array}{l}\text { Cukup meningkat. Data } \\
\text { manager suka kasih tau } \\
\text { puskesmas mana aja yang } \\
\text { pelacakan kontaknya } \\
\text { sudah baik dan yang } \\
\text { belum baik. Karena kita } \\
\text { pernah di bawah target, } \\
\text { jadi lebih gencar cari } \\
\text { kontak eratnya. }\end{array}$ & $\begin{array}{l}\text { Lumayan. Silacak kan dipantau } \\
\text { sama data manager dinkes, } \\
\text { biasanya kita dapat feedback } \\
\text { sebulan sekali puskesmas mana } \\
\text { aja yang tracingnya masih kurang } \\
\text { dan yang udah baik. Jadi secara } \\
\text { tidak langsung, kita jadi lebih } \\
\text { memperhatikan capaian kita, dan } \\
\text { berusaha untuk meningkatkan. }\end{array}$ & $\begin{array}{l}\text { Bisa meningkatkan. Dinas } \\
\text { kesehatan setiap awal atau } \\
\text { akhir bulan suka kasih tau, } \\
\text { Puskesmas ini } \\
\text { pencapaiannya berapa } \\
\text { persen, udah masuk target } \\
\text { atau belum. Kalau kurang, } \\
\text { kita usaha lagi. Kalau } \\
\text { sudah memenuhi target, } \\
\text { kita pertahankan. }\end{array}$ \\
\hline Meningkatkan & Harusnya sih meningkat & Loadingnya lama, meskipun & Kurang bisa produktif \\
\hline Produktivitas & $\begin{array}{l}\text { karena ada alat bantu } \\
\text { untuk pencatatan. Tapi } \\
\text { karena alatnya lambat, } \\
\text { justru malah } \\
\text { menghambat. }\end{array}$ & $\begin{array}{l}\text { koneksi kita cepat. Padahal masih } \\
\text { banyak pekerjaan yang menunggu, } \\
\text { seperti laporan PE, (aplikasi) } \\
\text { agregat, dan excel-excel dari } \\
\text { Dinas Kesehatan. }\end{array}$ & $\begin{array}{l}\text { karena sering ada } \\
\text { perbaikan di jam kerja. } \\
\text { Jadi pekerjaannya harus } \\
\text { ditunda dulu sampai selesai } \\
\text { perbaikannya. }\end{array}$ \\
\hline
\end{tabular}




\begin{tabular}{ll}
\hline \multicolumn{1}{c}{ Kriteria } & \multicolumn{1}{c}{ INF 1 } \\
\hline Persepsi Kebermanfaatan \\
Mempermudah & Lumayan mempermudah \\
Pekerjaan & karena data-data yang \\
& perlu diisi juga udah \\
& lumayan lengkap.
\end{tabular}

\section{Persepsi Kemudahan Penggunaan \\ Mudah Dipahami Mudah sih. Aplikasinya dan Digunakan \\ lebih mudah kalau dipraktikkan langsung.}

$\begin{array}{ll}\text { Pelatihan Khusus } & \begin{array}{l}\text { Ada pelatihan dengan } \\ \text { dinas kesehatan via zoom } \\ \text { beberapa hari sebelum } \\ \text { Dapat } \\ \text { Dikendalikan }\end{array} \\ & \text {...kalau ada pasien } \\ & \text { reinfeksi COVID, kan } \\ & \text { NIKnya udah kepake tuh, } \\ & \text { kita ga akan bisa daftarin } \\ & \text { lagi. Nah, solusinya kita } \\ & \text { tuh harus lapor dulu ke } \\ & \text { data manager, supaya } \\ & \text { datanya bisa ditampilkan } \\ & \text { lagi. Dan itu cukup } \\ & \text { memakan waktu. }\end{array}$

Fleksibel Mudah banget diakses. Bisa lewat hp atau laptop.
Lumayan, jadinya data yang didapatkan di lapangan bisa diinput disitu. Kalau di kertas kan bisa hancur atau hilang, kalau di sistem mungkin lebih aman.
Aplikasinya mudah dipelajari, pas praktiknya juga gampang karena bahasanya awam mungkin ya, gak pake bahasa-bahasa medis gitu.

Memang ada pelatihan tapi ga lama kok. Sama dinas kesehatan dan BNPB lewat zoom meeting.

Perbaikan data yang salah cukup mudah. Tapi kalau kasus reinfeksi harus kontak DM (data manager) untuk dimunculkan lagi.
Bisa mempermudah, kalau Silacak berintegrasi dengan Disdukcapil. Kalau tidak sering gangguan juga bisa mempermudah, karena kan kita masih harus input data yang sama ke sistem yang lain.

Gampang kok buat dipelajarin (Silacak). Pas dipakai juga mudah.

Ada, pelatihan online dengan dinas kesehatan tentang tata cara penggunaan Silacak. Kalau ada pasien yang NIKnya sama harus kontak DM, dan kalau ada pasien yang pernah diinput, terus sakit lagi juga harus kontak DM.
Bisa diakses di rumah, di puskesmas, pakai wifi, atau paket data. Biasanya saya pakai laptop biar enak lihat datanya.
Biasanya pakai handphone biar bisa dibawa mobile kalau kunjungan. Lewat handphone juga keliatan semua (data pasien).
Pengguna aplikasi Silacak di UPT Puskesmas Cipadung juga berharap agar pengembang dapat mempertimbangkan perbaikan untuk fitur-fitur aplikasi yang belum tersedia serta perbaikan untuk masalah aplikasi yang sering melambat setiap diakses pada saat jam kerja, serta agar aplikasi Silacak bisa menjadi aplikasi utama yang memudahkan sistem pelaporan. Adapun ringkasan wawancara dengan informan tersaji pada Tabel 2.

\section{PEMBAHASAN}

Menurut Peraturan Menteri Kesehatan Nomor HK.01.07/Menkes/413/2020 tentang Pedoman Pencegahan dan Pengendalian Coronavirus Disease 2019 (2020), setiap kasus suspek, probable, dan konfirmasi harus dilakukan penyelidikan epidemiologi menggunakan formulir. Hasil penyelidikan epidemiologi dipergunakan untuk memberikan masukan bagi pemangku kebijakan dalam rangka 
penanggulangan atau pemutusan penularan secara lebih cepat (11).

Sebagaimana diatur dalam Pedoman Pencegahan dan Pengendalian COVID-19 yang dibuat oleh Kementerian Kesehatan RI (2020), bahwa setiap kasus yang telah dilakukan penyelidikan epidemiologi harus dilakukan pelacakan kontak erat. Kontak erat yang sudah ditemukan harus dicatat dan dilaporkan secara harian, terkait status kesehatannya, tanggal kontak terakhir dengan kasus suspek/probable/konfirmasi. Sesuai dengan pedoman pencegahan dan pengendalian COVID-19, petugas pelacak kontak di UPT Puskesmas Cipadung selalu melakukan penyelidikan epidemiologi pada pasien terkonfirmasi serta mencatat hasilnya dalam Form 6 Penyelidikan Epidemiologi (12).

Data yang digali oleh petugas pelacak kontak saat melakukan penyelidikan epidemiologi diantaranya adalah identitas pasien, gejala klinis, komorbid, riwayat perjalanan, riwayat kontak, serta identitas orang-orang yang memiliki kontak erat dengan pasien. Setelah melakukan pencatatan di Form 6, petugas pelacak kontak melakukan pelaporan kasus konfirmasi dan kontak erat melalui aplikasi Silacak versi 1.2.5 dengan menggunakan akun dan kode akses masing-masing petugas. Pemberian akses kepada masingmasing petugas dimaksudkan untuk mencegah akses oleh orang yang tidak berwenang. Ini merupakan salah satu upaya pengembang untuk melindungi kerahasiaan data pasien COVID-19 dari ancaman keamanan. Proses penginputan kasus konfirmasi dilakukan setiap satu hingga dua hari sekali, tergantung adanya penemuan kasus baru (notifikasi) di wilayah kerja UPT Puskesmas Cipadung dan kondisi aplikasi Silacak.

Aplikasi Silacak versi 1.2.5 telah dilengkapi dengan e-book dan video pedoman penggunaan. Hal ini dimaksudkan untuk mengurangi terjadinya kesalahan pengoperasian sistem informasi yang diakibatkan oleh faktor manusia (human error). Kesalahan pengoperasian sistem akibat human error dapat mengancam integritas sistem dan kualitas data (13).

Perangkat keras yang paling sering digunakan oleh petugas pelacak kontak untuk mengakses Silacak ialah laptop dan telepon genggam. Hal ini dilakukan karena laptop dan telepon genggam lebih mudah untuk digunakan dan dibawa, khususnya untuk melakukan pendataan di lapangan. Telepon genggam (smartphone) pada masa kini juga sudah menjadi alat yang dimiliki oleh setiap individu dan telah dilengkapi dengan koneksi internet yang dapat dengan mudah disinergikan dengan laptop untuk pemanfaatan yang lebih baik.

Pada aplikasi Silacak versi 1.2.5 hampir seluruh kolom diberi tanda bintang (*) yang berarti hampir seluruh kolom 
memiliki atribut required atau wajib diisi. Form tidak akan berhasil disimpan hingga seluruh kolom yang memiliki atribut required selesai diisi (14). Atribut ini disisipkan oleh pengembang untuk meminimalisir kesalahan petugas saat memasukkan data. Dari seluruh kolom yang tersedia di aplikasi Silacak versi 1.2.5, kolom yang tidak rutin diisi oleh petugas pelacak kontak di UPT Puskesmas Cipadung ialah kolom koordinat. Berdasarkan hasil pengamatan, kolom koordinat tidak selalu diisi dikarenakan tidak menentunya jadwal kunjungan rumah dan lambatnya proses mendapatkan titik koordinat.

Petugas pelacak kontak di UPT Puskesmas Cipadung memiliki salinan data kasus COVID-19 dan kontak eratnya dalam bentuk Formulir Penyelidikan Epidemiologi dan google spreadsheet yang otomatis tersimpan pada sistem cloud google drive. Salinan data (back up data) ini dimaksudkan untuk mengantisipasi kemungkinan terjadinya kerusakan atau hilangnya data primer. Sebagaimana dijelaskan oleh Sinaga (2020), back up data dapat dilakukan dengan membuat salinan data fisik atau file ke penyimpanan sekunder. Salah satu media penyimpanan sekunder ialah sistem cloud (15).

Setelah data selesai diinput ke Silacak, data secara otomatis diterima oleh data manager di Dinas Kesehatan Kota
Bandung dan akan ditampilkan pada dashboard. Data yang ditampilkan pada dashboard berupa angka dan diagram titik jumlah kasus dan kontak erat. Menurut Hariyanti, Werdiningsih, dan Surendro (2011) dashboard adalah alat yang digunakan untuk memonitor kinerja dalam bentuk visual (16). Menurut Eckerson (2006) dalam Wijayanto (2011) salah satu manfaat dashboard ialah untuk menyajikan informasi menggunakan grafik, bagan, dan simbol untuk memudahkan pengguna dalam memahami dan membuat persepsi yang benar. Namun berdasarkan hasil pengamatan, dashboard pada aplikasi Silacak cukup sulit untuk diakses karena laman untuk melihat dashboard dan laman untuk menginput data berbeda sehingga tidak semua pengguna mengetahui keberadaan dashboard pada sistem ini (17).

\section{Persepsi Kebermanfaatan}

Berdasarkan hasil wawancara, indikator persepsi kebermanfaatan yang telah dianggap cukup baik ialah kinerja dan efektivitas kinerja, mempermudah pekerjaan pengguna, serta manfaat sistem secara keseluruhan.

\section{a. Meningkatkan Kinerja dan Efektivitas Kinerja}

Penggunaan teknologi informasi sebaiknya mampu meningkatkan kinerja pengguna. Meningkatkan kinerja yang dimaksud pada hal ini ialah melalui 
pemanfaatan teknologi informasi, hasil pekerjaan yang diperoleh sebaiknya meningkat dan dapat memenuhi target (18). Menurut Daft (1982) efektivitas kinerja ialah kemampuan untuk mencapai hasil kerja maksimal sesuai dengan sasaran yang telah ditetapkan (19). Pada hal ini, Silacak versi 1.2.5 secara tidak langsung membantu meningkatkan kinerja petugas. Dikarenakan petugas harus menunggu umpan balik dari Dinas Kesehatan mengenai kinerja timnya. Meskipun begitu, hasil penelitian Yueh, Lu \& Lin (2016) menyatakan bahwa terdapat hubungan yang positif antara peningkatan kinerja atau performa pegawai dengan tingkat penerimaan teknologi (20).

\section{b. Mempermudah Pekerjaan}

Teknologi dan sistem informasi memiliki peran vital pada manajemen, hal tersebut dikarenakan sistem informasi dapat berkontribusi terhadap kemajuan suatu organisasi. Sistem informasi dimaksudkan untuk mempermudah pekerjaan administratif. Sistem informasi dapat membantu mempermudah pekerjaan dalam hal menyimpan, menganalisis, komunikasi, analisis data, menghemat waktu dan biaya, meningkatkan pemanfaatan sumber daya manusia, pengembangan dan pembuatan keputusan (21). Pada hal ini, Silacak versi 1.2.5 telah mampu mempermudah pekerjaan petugas pelacak kontak dengan kemampuannya menyimpan, melakukan transfer data secara vertikal dari Puskesmas ke tingkat Dinas Kesehatan dan menghemat waktu dan biaya petugas pelacak kontak.

\section{c. Manfaat Keseluruhan}

Secara keseluruhan, pengguna merasa aplikasi Silacak memiliki manfaat sebagai media komunikasi untuk menyampaikan situasi pandemi COVID-19 berdasarkan wilayah. Silacak juga menjadi wadah untuk menyimpan dan pemantauan kondisi kesehatan kasus konfirmasi dan kontak eratnya.

Indikator persepsi kebermanfaatan yang masih dirasa kurang oleh pengguna diantaranya indikator meningkatkan produktivitas dan mempercepat kerja.

\section{d. Meningkatkan Produktivitas}

Menurut Yuniarsih dan Suwatno (2009) dalam Chandra dan Prasetya (2015), produktivitas kerja adalah hasil konkrit yang dihasilkan oleh individu atau kelompok, selama satuan waktu tertentu dalam suatu proses kerja. Kehadiran sistem informasi idealnya mampu meningkatkan produktivitas kerja. Namun Silacak belum memenuhi kriteria ini dikarenakan banyaknya sistem yang digunakan untuk pelaporan COVID-19, proses penyimpanan data yang dirasa cukup lama karena sering terjadi gangguan teknis dan belum terintegrasinya Silacak dengan Disdukcapil $(22,23)$. Menurut Noviastuty, Herdiani, dan Ginanjar (2019) integrasi sistem dapat membantu meningkatkan kecepatan dan mempermudah proses administrasi. Oleh 
karena itu, dengan adanya integritas akan dapat membantu petugas untuk bekerja lebih produktif (24).

\section{e. Mempercepat Pekerjaan}

McGuire (2003) menyatakan bahwa sistem informasi dapat membantu memfasilitasi pekerja dalam mempercepat pengumpulan data, pengkategoriasian, pengaksesan, dan pertukaran data. Namun Silacak versi 1.2 .5 belum memenuhi kriteria ini, pengguna seringkali merasa Silacak memiliki waktu tanggap sistem (system response time) yang terlalu lama (25). Waktu tanggap sistem ialah tantangan terbesar pada pelaksanaan sistem informasi kesehatan (26), hal ini juga mampu mempengaruhi produktivitas kerja. Sehingga perlu adanya perhatian khusus pada aspek ini.

\section{Persepsi Kemudahan}

Pada persepsi kemudahan, indikator yang dirasakan sudah cukup baik oleh pengguna ialah kemudahan dalam mempelajari, menggunakan, dan fleksibilitas aplikasi Silacak, sedangkan indikator yang masih dirasakan kurang diantaranya ialah aplikasi Silacak dirasa kurang mudah untuk dikendalikan.

\section{a. Mudah Dipelajari dan Digunakan}

Sistem yang mudah dipelajari, dan mudah digunakan akan mendorong pengguna untuk menggunakan sistem sebagai alat bantu dalam menyelesaikan tugas (27). Aplikasi Silacak versi 1.2.5 telah memenuhi indikator ini, hal ini dibuktikan melalui pernyataan pengguna yang tidak merasa kesulitan dalam memahami dan mengoperasikan aplikasi Silacak.

\section{b. Fleksibel}

Fleksibilitas

menggambarkan kemampuan sistem informasi untuk dapat di implementasikan pada segala jenis dan spesifikasi sistem komputer yang tersedia di pasaran (28). Indikator fleksibilitas pada aplikasi Silacak telah terpenuhi. Hal ini dibuktikan melalui pernyataan pengguna yang menyatakan bahwa aplikasi Silacak dapat digunakan kapan saja, dimana saja, dengan media apa saja.

\section{c. Dapat Dikendalikan}

Menurut Jogiyanto (2009) dalam Fahlevi (2019) penerapan sebuah teknologi informasi memerlukan sistem pengendalian untuk kemudahan sistem itu sendiri. Salah satu komponennya ada pada sistem teknologi informasi yaitu komponen kontrol atau pengendalian. Namun pada aplikasi Silacak indikator ini kurang dapat dirasakan. Petugas harus menghubungi data manager untuk mengembalikan data yang pernah dikirim. Hal ini dimaksudkan untuk menghindari terjadinya redudansi data, namun kurang menerapkan prinsip CRUD. Oleh karena itu, perlu adanya perhatian khusus pada aspek ini $(18,29)$.

\section{KESIMPULAN}


Pendataan pasien COVID-19 di UPT Puskesmas Cipadung telah sesuai dengan pedoman pencegahan dan pengendalian COVID-19 yang diterbitkan oleh Kementerian Kesehatan RI. Perangkat untuk menunjang kegiatan pencatatan dan pelaporan menggunakan aplikasi Silacak versi 1.2.5 telah tersedia dalam kondisi baik.

Penerimaan pengguna pada aplikasi Silacak versi 1.2.5 sudah cukup baik. Hal tersebut terlihat dari banyaknya indikator yang telah terpenuhi, jika dibandingkan dengan indikator yang belum terpenuhi. Indikator pada persepsi kebermanfaatan yang telah terpenuhi ialah meningkatkan kinerja dan efektivitas kinerja, mempermudah pekerjaan, manfaat keseluruhan. Indikator pada persepsi kemudahan yang telah terpenuhi ialah mudah dipelajari dan digunakan, serta fleksibilitas sistem.

$$
\text { Indikator pada persepsi }
$$

kebermanfaatan yang belum terpenuhi ialah membantu pekerjaan lebih cepat dan meningkatkan produktivitas kerja, sedangkan indikator pada persepsi kemudahan yang belum terpenuhi ialah kemudahan dalam mengendalikan sistem.

Saran yang dapat diberikan yaitu dilakukan pengembangan terhadap aplikasi Silacak agar dapat terkoneksi dengan data Disdukcapil untuk membantu mempercepat dan mempermudah proses administrasi pencatatan dan pelaporan kasus COVID-19. Dilakukan integrasi sistem antara aplikasi Silacak dengan aplikasi pelaporan COVID19 lainnya, agar dapat meningkatkan produktivitas. Sebaiknya pengembang memperbaiki letak dashboard agar lebih mudah diakses oleh pengguna, sehingga pengguna dapat mengetahui kinerjanya sendiri dan berusaha untuk meningkatkan atau mempertahankannya. Perlu adanya penyelidikan lebih lanjut di tingkat pusat untuk mengetahui penyebab terjadinya lamanya waktu tanggap (response time) Silacak versi 1.2.5.

\section{DAFTAR PUSTAKA}

1. Susilo A, Rumende CM, Pitoyo CW, Santoso WD, Yulianti M, Herikurniawan $\mathrm{H}$, et al. Coronavirus Disease 2019: Tinjauan Literatur Terkini. J Penyakit Dalam Indones. 2020;7(1):45-67.

2. Direktorat Jenderal Pelayanan Kesehatan Kementerian Kesehatan RI. Petunjuk Teknis Pelayanan Puskesmas Pada Masa Pandemi COVID-19. Jakarta: Kesehatan Kementerian Kesehatan RI; 2020.

3. Nsubuga P, White ME, Thacker SB, Anderson MA, Blount SB, Broome C V., et al. Public Health Surveillance: A Tool for Targeting and Monitoring 
Interventions. In: Jamison DT, Breman JG, Measham AR, Alleyne G, Claeson M, Evans DB, et al., editors. Disease Control Priorities in Developing Countries. 2nd ed. Washington DC: The International Bank for Reconstruction and Development / The World Bank; 2006. p. 997-1015.

4. Sutabri T. Konsep Sistem Informasi. Yogyakarta: Andi; 2012.

5. WHO. Ikhtisar Kegiatan: Coronavirus Disease 2019 (COVID. Geneva; 2020.

6. Surendran P. Technology Acceptance Model: A Survey of Literature. Int J Bus Soc Res. 2012;2(4):175-8.

7. Davis FD. Perceived usefulness, perceived ease of use, and user acceptance of information technology. MIS Q Manag Inf Syst. 1989;13(3):319-39.

8. Irmadhani, Nugroho MA. Pengaruh Persepsi Kebermanfaatan, Persepsi Kemudahan Penggunaan dan Computer Self Efficacy terhadap Penggunaan Online Banking Pada Mahasiswa S1 Fakultas Ekonomi Universitas Negeri Yogyakarta. Kaji Pendidik Akunt Indones. 2012;1(3):1-20.

9. Noviarni E. Analisis Adopsi Layanan Internet Bangking oleh Nasabah Perbankan di Pekanbaru (Technology
Acceptance Model). J ALIQTISHAD. 2017;10(1):26-39.

10. Deisti ARF. Retail Web: Pengaruh Technology Acceptance Model (TAM) terhadap Perilaku Adopsi Konsumen. [Bandung]: Politeknik Negeri Bandung; 2018.

11. KemenkesRI. Keputusan Menteri Kesehatan Republik Indonesia Nomor HK.01.07/MenKes/413/2020 Tentang Pedoman Pencegahan dan Pengendalian Corona Virus Disease 2019 (Covid-19). MenKes/413/2020. 2020;2019:1-207.

12. Kementrian Kesehatan Republik Indonesia (Kemenkes RI). Pedoman Pencegahan dan Pengendalian Coronavirus Disease (Covid-19) Revisi Ke-5. Jakarta; 2020.

13. Paryati P. Keamanan Sistem Informasi. Semin Nas Inform. 2015;1(4):379-86.

14. Hari Mulyawan K. Manajemen Data dengan Epi Info v.7. Universitas Udayana. Denpasar; 2017.

15. Sinaga AS. Keamanan Komputer. Solok: ICM Publisher; 2020.

16. Hariyanti E, Werdiningsih I, Surendro K. Model Pengembangan Dashboard untuk Monitoring dan Evaluasi Kinerja Perguruan Tinggi. JUTI J Ilm Teknol Inf. 2011;9(1):13-20.

17. Wijayanto YA. Perancangan Dashboard sebagai Sistem Informasi 
Monitoring Kinerja Universitas

Sebelas Maret Surakarta. [Surakarta]:

Universitas Sebelas Maret; 2011.

18. Fahlevi P, Octaviani Puspita Dewi A. Analisis Aplikasi iJateng dengan Menggunakan Teori Technology Acceptance Model (TAM). J Ilmu Perpust. 2019;8(2):103-11.

19. Daft RL. Bureaucratic versus Nonbureaucratic Structures and the Process of Innovation and Change. In: Bacharach SB, editor. Research in the Sociology of Organisations. Greenwich: JAI Press; 1982. p. 12966.

20. Yueh HP, Lu MH, Lin W. Employees' acceptance of mobile technology in a workplace: An empirical study using SEM and fsQCA. J Bus Res. 2016 Jun 1;69(6):2318-24.

21. Belkur AA, Mehta R, Shafter MS, Amar AA. The Role of Management Information Systems in Increasing the Effectiveness of Managerial Decision Making. The Case of the General Company for Cement and Building Materials Study in Libya. Int J Eng Res Technol. 2017;6(1).

22. Yuniarsih T, Suwatno. Manajemen Sumber Daya Manusia; Teori, Aplikasi, dan Isu Penelitian . 2009. Bandung: Alfabeta; 2009.

23. Prasetya W, Chandra A. Peningkatan Produktivitas melalui Peningkatan
Kualitas Kerja, Kepemimpinan, dan Kompensasi pada PT. Kmk Global Sports. E-Journal Widya Ekon. 2015;1(1):58-63.

24. Noviastuty R, Herdiani L, Ginanjar A. Perancangan Sistem Integrasi Administrasi Dan Keuangan Dalam Pelayanan Tera dan Tera Ulang Timbangan. J TIARSIE. 2019;16(2):45-52.

25. Agranoff R, McGuire $\mathrm{M}$. Collaborative public management: New strategies for local governments | Request PDF. Washington, D.C.: Georgetown University Press; 2003.

26. Farzandipour M, Meidani Z, Nabovati E, Sadeqi Jabali M, Dehghan Banadaki R. Technical requirements framework of hospital information systems: design and evaluation. BMC Med Informatics Decis Mak 2020 201. 2020;20(1):1-10.

27. Handiwidjojo W, Ernawati L. Pengukuran Tingkat Ketergunaan (Usability) Sistem Informasi Keuangan Studi Kasus: Duta Wacana Internal Transaction (Duwit) | Jurnal Informatika dan Sistem Informasi. JUISI. 2016;2(1):49-55.

28. Supriyatna D, Jin TF. nalisis Pengaruh Kepuasan Pengguna Public Computer Terhadap Efisiensi dan Efektivitas Mahasiswa Trisakti School of Management. J Bisnis dan Akunt. 
2006;8(2):111-34.

29. Jogiyanto. Sistem Informasi

Manajemen. Yogyakarta: ANDI;

2009. 